DOI: https://doi.org/10.15407/techned2020.05.074

\title{
MAGNETIC FORCES AND CURRENTS OF THE INDUCTOR FOR MAGNETIC-PULSE PROCESSING OF OF WELDING JOINTS OF NON-MAGNETIC THIN SHEET METALS
}

$\quad$ Journal
Publisher
ISSN
Issue
Pages

\author{
Tekhnichna elektrodynamika \\ Institute of Electrodynamics National Academy of Science of Ukraine \\ 1607-7970 (print), 2218-1903 (online) \\ No 5, 2020 (September/October) \\ $74-79$
}

\begin{abstract}
Authors
A.P. Raschepkin ${ }^{\star}$, I.P. Kondratenko**, A.N. Karlov***, R.S. Kryshchuk ${ }^{\star \star \star \star}$ Institute of Electrodynamics, National Academy of Sciences of Ukraine, Peremohy Ave., 56, Kyiv, 03057, Ukraine, e-mail: anatoly_raschepkin@ukr.net, dep7ied@ukr.net, lexa.k.ua@gmail.com , kr@nas.gov.ua

${ }^{*}$ ORCID ID : https://orcid.org/0000-0002-3308-8032

** ORCID ID : https://orcid.org/0000-0003-1914-1383

*** ORCID ID : https://orcid.org/0000-0002-1350-1870

**** ORCID ID : https://orcid.org/0000-0002-1933-0144
\end{abstract}

\begin{abstract}
In order to eliminate residual stresses in the welds of thin-sheet non-magnetic metals, the possibility of using magnetic pulse processing is considered. An electromagnetic inductor with a $U$-shaped magnetic circuit and two coils of solid conductor is considered. To create a unipolar current pulse in the inductor winding, a trinistor is used, which switches the electrical circuit from the capacitor, inductance and active resistance, and when the current in the inductor winding reaches zero, the circuit opens. The calculation of the transient process in an electric circuit with a dynamically changing inductance is performed by solving a circuit-field problem with given initial conditions. The calculation of the electromagnetic field is performed by the finite element method for a two-dimensional model of the inductor. The study of electromagnetic processes in the inductor and thin-sheet non-magnetic workpieces with the amplitude of the maximum current density of $1 \mathrm{kA} / \mathrm{mm}^{2}$. The distribution of current density and magnetic force density on the workpiece surface and in time is given. It is proved that only for a small thickness of welded products $(2 \mathrm{~mm})$ can be achieved simultaneous power and current.
\end{abstract}


References 9, figures 4.

Key words: magnetic pulse processing, pulse inductor, transients, U-shaped core.

Received: 13.03 .2020

Accepted: 06.05.2020

Published: 25.08.2020

\section{References}

1. Baranov Yu.V., Troitsky O.A., Avraamov Yu.S., Shlyapin A.D. Physical fundamentals of electropulse and electroplastic treatments and new materials. Moskva: MGIU, 2001. 844 p. (Rus)

2. Lobanov L.M., Pashchin N.A., Loginov V.P., Loginova Yu.V. The use of electric pulse processing of structural elements in order to increase their resource. Avtomaticheskaia svarka. 2005. No 11. Pp. 26-30. (Rus)

3. Lobanov L.M., Kondratenko I.P., Zhyltsov A.V., Karlov O.M., Pashchyn M.O., Vasyuk V.V., Yashchuk V.A. Electrophysical unsteady processes in the system to reduce residual stresses welds. Tekhnichna elektrodynamika. 2016. No 6. Pp. 10-19. (Rus) DOI: https://doi.org/10.15 407/techned2016.06.010

4. Neumann L.R., Kalantarov P.L. Theoretical Foundations of Electrical Engineering, Part 2. Moskva-Leningrad: HEl, 1959. 444 p. (Rus)

5. Samohvalov V.N., Samohvalova Zh.V. Magnetic-pulse and electric pulse treatment of machine parts Sovremennye problemy teorii mashin, 2017. No 5. Pp. 113-115. (Rus)

6. Tamm I.E. Theory of electricity. Moskva: Nauka, 1976. 616 p. (Rus)

7. Lobanov L.M., Pashchin N.A., Mikhoduy O.L., Sidorenko Yu.M. The effect of the electric pulse component on the stress state of welded joints of the AMg6 aluminum alloy during electrodynamic processing. Problemy prochnosti. 2018. No 2. Pp. 18-26. (Rus) DOI: https://doi .org/10.1007/s11223-018-9965-x

8. Seidametov S.V., Loskutov S.V. The influence of pulse electromagnetic field on rebuilding of structure of titanium alloy vt3-1. Zhurnal fizyky ta inzhenerii poverkhni. 2016. Vol. 1. Pp. 4-8. (Rus)

9. Kuznetsov N.N. Influence of electroimpulse and magnetoimpulse effects on the workpiece. Obrabotka materialov davleniem

. 2010. No 3(24). Pp. 126-129. (Rus) 
$\underline{\text { PDF }}$

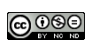

This work is licensed under a Creative Commons Attribution-NonCommercial-NoDerivatives $\underline{4.0 \text { International License }}$ 